

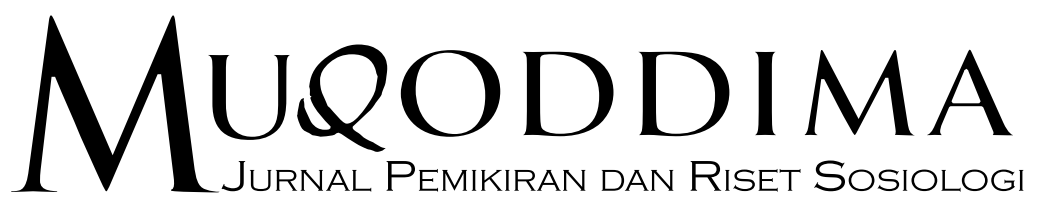




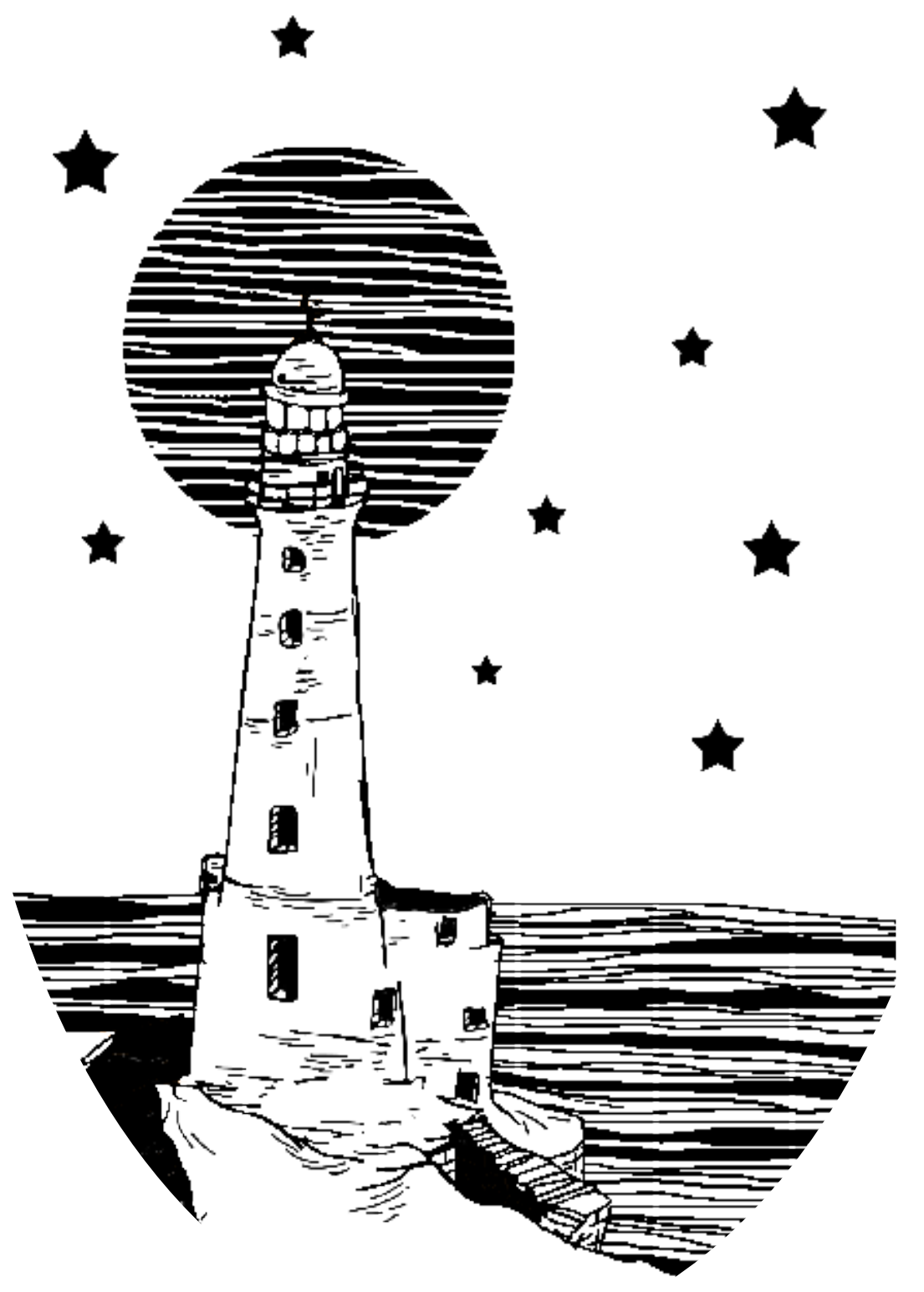




\section{MUQOdDIMA \\ JuRnal PEMIKIRAN DAN Riset SOSIOLOGI}

Vol. 1 No. 2 Desember 2020

ISSN 2745-7168 (DARING)

\section{Editor in Chief}

Eneng Darol Afiah, Universitas Nahdlatul Ulama Indonesia Jakarta

\section{Managing Editor}

Naeni Amanulloh, Universitas Nahdlatul Ulama Indonesia Jakarta

\section{Editor}

Amsar A. Dulmanan, Universitas Nahdlatul Ulama Indonesia Jakarta

Pangeran P.P.A. Nasution, Universitas Malikussaleh

Muhammad Nurul Huda, Universitas Nahdlatul Ulama Indonesia Jakarta

Muhammad Mustafid, Universitas Nahdlatul Ulama Yogyakarta

Mujtaba Hamdi, Universitas Nahdlatul Ulama Indonesia Jakarta

Fikri Tamau, Universitas Pembangunan Nasional Veteran Jakarta

Hanifa Maulidia, Sekolah Tinggi Imigrasi

Dewi Anggraeni, Universitas Nahdlatul Ulama Indonesia Jakarta

Muhammad Nurun Najib, Universitas Nahdlatul Ulama Indonesia Jakarta

R.M. Joko P. Mulyadi, Universitas Nahdlatul Ulama Indonesia Jakarta

Moh. Faiz Maulana, Universitas Nahdlatul Ulama Indonesia Jakarta

\section{Reviewer}

Achmad Munjid, Universitas Gajah Mada, Yogyakarta, Indonesia

Ahmad Suaedy, Universitas Nahdlatul Ulama Indonesia, Jakarta, Indonesia

Syamsul Hadi, Universitas Nahdlatul Ulama Indonesia, Jakarta, Indonesia

Moh. Yasir Alimi, Universitas Negeri Semarang, Semarang, Indonesia

Nadiatus Salama, Universitas Islam Negeri Walisongo, Semarang, Indonesia

Anton Novenanto, Universitas Brawijaya, Malang, Indonesia

Akhmad Ramdhon, Universitas Sebelas Maret, Surakarta, Indonesia

Imam Ardhianto, Universitas Indonesia, Jakarta, Indonesia

Achmad Fawaid, Universitas Nurul Jadid, Probolinggo, Indonesia

Fariz Alnizar, Universitas Nahdlatul Ulama Indonesia, Jakarta, Indonesia

Pajar Hatma Indra Jaya, Universitas Islam Negeri Kalijaga, Yogyakarta, Indonesia

\section{Ilustrasi Cover}

'Menara Petunjuk', Shilfina Putri Widatama 
MUQODDIMA Jurnal Pemikiran dan Riset Sosiologi diterbitkan oleh Laboratorium Sosiologi, Departemen Sosiologi, Fakultas Sosial dan Humaniora, Universitas Nahdlatul Ulama Indonesia (UNUSIA) Jakarta. Jurnal ini terbit dua kali setahun, yaitu pada Juni dan Desember.

MUQODDIMA Jurnal Pemikiran dan Riset Sosiologi menyajikan karya-karya ilmiah di bidang sosiologi dan sosial humaniora. MUQODDIMA Jurnal Pemikiran dan Riset Sosiologi mengarahkan diri pada kajian sosial-keagamaan, budaya, politik-ekonomi, serta isuisu kemanusiaan dan lingkungan hidup baik yang dihasilkan dari penelitian lapangan maupun tinjauan kritis atas teori sosial. MUQODDIMA Jurnal Pemikiran dan Riset Sosiologi mengundang para akademisi dan peneliti di bidang sosial humaniora, khususnya sosiologi, serta para praktisi/aktivis sosial untuk mengirimkan karyanya.

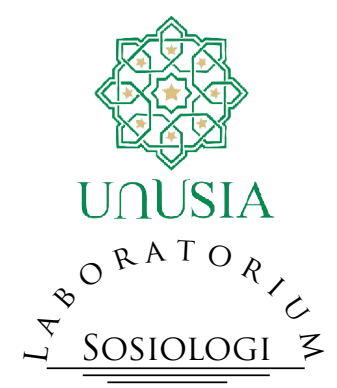

\author{
Alamat Editorial: \\ Kampus UNUSIA Jakarta \\ Jl. Taman Amir Hamzah No. 5 \\ Jakarta Pusat 10430 \\ Telp/Fax: (021) 3156864 / 3906501 \\ E-mail: muqaddima.jms@unusia.ac.id \\ Website: http://journal.unusia.ac.id/index.php/Muqoddima
}




\section{MUgODdima \\ JuRnal PEMikiran dan Riset Sosiologi}

Vol. 1 No. 2 Desember 2020

\section{DAFTAR IsI}

\section{Pengantar Editorial}

$i-x \mid$ Eneng Darol Afiah

Membaca Ulang 'Guncangan Besar' Francis Fukuyama

\section{Artikel}

113-132 | RaCHMAD K. Dwi SUSILO

Sosiologi Sebagai the Queen of Social Sciences: Sebuah Refleksi

133-144 Taufik Hidayadi \& Henny Saptatia Drajati Nugrahani Stereotip Warga Tionghoa dalam Geopolitik Hubungan Indonesia dengan Tiongkok

145-164 FARIZ ALNIZAR

Antara Iman dan Kenikmatan:

Konstruksi Gagasan Pascamodernisme Ariel Heryanto

165-180 Nana KristiaWAN

Dinamika Pengelolaan Sumber Daya Air di Situ Kemuning, Cimanggis Kabupaten Bogor

181-196 IndHAR WAHYU Wira HaRJo

Konsolidasi Demokrasi Melalui Liga Santri Nusantara

197-210 MoH. Faiz Maulana

Dangdut Koplo: Tubuh, Seksualitas, dan Arena Kekuasaan Perempuan

211-230 ELMY BONAFITA ZAHRO

Smoking Outcome Expectancy: Pengetahuan, Perilaku, dan Konsekuensi Merokok

TelaAh Buku

231-234 Muhammad Nurun Najib

Kembalinya Politik Identitas dan Identitas Nasional 


\title{
Antara Iman dan Kenikmatan: Konstruksi Gagasan Pascamodernisme Ariel Heryanto
}

\author{
Fariz Alnizar \\ Program Studi Pendidikan Agama Islam Universitas Nahdlatul Ulama Indonesia \\ E-mail: fariz@unusia.ac.id
}

\begin{abstract}
Abstrak
Artikel ini bertujuan untuk menggambarkan konstruksi gagasan pascamodernisme Ariel Heryanto. Melalui kajian pengamatan mendalam pada beberapa artikel dan terutama pada buku Identity and Pleasure: The Politics of Indonesian Screen Culture, artikel ini berhasil meyimpulkan bahwa epistemologi pascamodernisme menjadi tumpuhan analisis Ariel dalam melihatperkembanganbudaya populerdiIndonesiadewasaini. ArielHeryanto meminjam serangkaian epistemologi pacamodernisme salah satunya untuk melihat gejala budaya populer yang melahirkan gugusan identitas baru yang mencoba meruntuhkan identitas lama yang selama ini telah diberikan oleh penguasa. Identitas keindonesiaan yang menyangkut pemaknaan menjadi muslim Indonesia, bagaimana identitas tentang keminoritasan, baik ras maupun golongan tertentu (Kiri dan PKI), dan ekspresi memilih kenikmatan dengan sekaligus meneguhkan dan membangun identitas dalam konteks kegandrungan muslimah kelas menengah terhadap K-Pop dan K-Drama serta budaya populer berbasis layar lainnya. Ariel Heryanto berhasil membaca fenomena adanya generasi yang mencoba merumuskan ulang bagaimana menjadi muslim yang taat, bagaimana menjadi warga negara yang baik sekaligus di saat yang bersamaan tetap eksis menjadi anggota komunitas produsen dan konsumen global.
\end{abstract}

Kata Kunci: Pascamodernisme, epistemologi, Ariel Heryanto, budaya populer, Indonesia 


\begin{abstract}
This article aims to describe the construction of Ariel Heryanto's postmodernism ideas. Through in-depth observational studies on several articles, especially on the book entitled Identity and Pleasure: The Politics of Indonesian Screen Culture, this article concludes that post-modern epistemology is the foundation of Ariel's analysis in seeing the development of popular culture in contemporary Indonesia. Ariel Heryanto used the postmodernism epistemology to see indications of popular culture. Indonesian identity which concerns to the meaning of being Indonesian Muslims, identity of minority (being Left and PKI), and expressions of choosing enjoyment while simultaneously affirming and building the identity in the context of middleclass Muslim fondness for K-Pop and K-Drama and other screen-based popular culture. Ariel Heryanto has succeeded in reading the phenomenon of a generation that try to redefine how to be a good Muslim, how to be a good citizen and at the same time remain a member of the global producer and consumer community.
\end{abstract}

Keywords: postmodernism, epsitemology, Ariel Heryanto, pop-culture, Indonesia.

\title{
Pendahuluan
}

Artikel ini bertujuan untuk memaparkan konstruksi gagasan pascamodernisme dalam karya Ariel Heryanto. Sebagai salah satu pemikir yang memiliki perhatian pada isu-isu kontemporer, Ariel memiliki pandangan luas dan tajam soal kebudayaan di Indonesia. Salah satu folus kajian dan pemikiranya adalah budaya populer pada masyarakat Indonesia dewasa ini. Melalui kajian analitis pada karya yang dihasilkan dalam buku Identity and Pleasure: The Politics of Indonesian Screen Culture (2014) artikel ini dimaksudkan untuk mengungkapkan bukti gagasan epistemologi pascamodernisme yang digunakan oleh Ariel Heryanto dalam mengkaji kebudayaan populer di Indomesia.

Istilah yang digunakan dalam artikel ini adalah pascamodernisme. Ini dipilih sebagai sebuah bentuk penghargaan pada bahasa Indonesia yang telah memiliki padanan atas kata postmodernisme (Pusat Bahasa Departemen Pendidikan Nasional 2008: 834). Sugiharto (1996: 15) mengartikan pascamodernisme sebagai "kata ini tidak memunyai arti. Gunakan saja sesering mungkin". Istilah pascamodernisme merupakan istilah yang sangat kontroversial. Pada satu pihak istilah ini acap dijadikan cemoohan, olok-olok dengan cara yang sinis, baik yang terjadi di bidang seni, filsafat, atau bidang-bidang yang lainnya, yakni dianggap sebagai sebuah sebuah mode intelektual yang dangkal dan kosong atau sekedar refleksi yang bersifat reaksioner belaka terhadap perubahan sosial yang sedang berlangsung (Butler 2002; Dator 2004; Mazer 1998).

Istilah Pascamodern dengan menggunakan bentuk 'post', pertama kali muncul di wilayah seni. Hasan (1985: 8) mencatat bahwa istilah pascamodernisme digunakan oleh Frederico de Onis dalam karyanya yang bertajuk "Antologia de la Poesia Espanola a Hispanoamericana" pada tahun 1930. Kemudian Arnold 
Toynbee di bidang historiografi pada tahun 1947. Toynbee menggunakan istilah pascamodernisme dalam bukunya yang sangat penting berjudul "A Study of History".

Di bidang kebudayaan, Jameson (1997: 85) menggunakan istilah pascamodernisme untuk mendanadai logika kultural yang membawa serangkaian transformasi kebudayaan. Dalam pandangan ini, pascamodernisme muncul dan diyakini akibat dominasi teknologi reproduksi dalam jaringan global kapitalisme yang bersifat multinasional saat itu. Baudrillard (1994) mengaitpautkan secara langsung antara modernisme dengan pascamodernisme. Baginya, jika modernisme ditandai dengan komodifikasi, mekanisasi, pasar, dan teknologi, maka masyarakat pascamodernisme ditandai dengan implosi atau ledakan ke dalam yang dicirikan dengan semakin kabur dan sumirnya batas wilayah kebudayaan yang disebut sebagai kebudayaan tinggi dan kebudayaan rendah, gambar atau penampilan dengan kenyataan, serta segala bentuk oposisi biner yang selama ini dipelihara secara terus menerus oleh teori sosial maupun filsafat tradisional.

Dalam bidang filsafat, istilah pascamodernisme pertama kali diperkenalkan oleh Lyotard dalam bukunya yang bertajuk "The Postmodern Condition: a Report on Knowledge (1984)". Bagi Lyotard (1984: 82) posisi-posisi pengetahuan di abad ini perlu ditinjau ulang dan dikaji lebih dalam. Utamanya menyangkut persoalan bagaimana ilmu pengetahuan dilegitimasikan melalui - apa yang diistilahkannya dengan 'narasi besar' yang antara lain terdiri dari kemajuan, kebebasan, emansipasi dan seterusnya. Bagi Lyotard narasi besar sesungguhnya akan mengalami nasib yang sama dengan dengan narasi-narasi besar pendahulunya: negara-bangsa, kepercayaan akan keunggulan Barat, nilai-nilai religi dan sebagaianya. Secara ringkas pandangan ini berarti mengartikan pascamodernisme sebagai sebauah periode pendelegitimisian segala sesuatu atau bisa juga dikatakan bahwa pascamodernisme adalah proses yang tak pernah berhenti dalam mencari sebuah kebaruan. Dalam bahasa Lyotard (1984: 12) pascamodernisme adalah "segala bentuk refleksi kritis atas paradigma-paradigma modern dan metafisika pada umumnya".

Di pihak lain, pascamodernisme juga diartikan gerakan kebudayaan pada umumnya, yang dicirikan oleh penentangan terhadap totalitarianisme, serta universalisme, serta kecenderungan ke arah keanekaragaman, ke arah melimpahruah dan timpang-tindihnya berbagai citra, gaya, sehingga menimbulkan fragmentasi, kontradiksi, dan pendangkalan. Pandangan ini akan berguna untuk mengungkap sebagain ciri-ciri dari pandangan aliran pascamodern. Utamanya yang menyangkut arena kebudayaan.

Asumsi dasar yang dibangun oleh pascamodernisme adalah (1) kepercayaan akan kedaulatan yang otonom yang dimiliki oleh setiap individu, (2) pascamodernisme meyakini adanya genealogi yang menyatakan bahwa ilmu penegatahuan datang dan dibuat dengan berdasarkan kepentingan manusia yang tentu saja dibatasi oleh ruang dan waktu, (3) adanya kepercayaan akan pendekatan tekstualisme. Ini berarti segala sesuatu diperlakukan sebagai teks yang terbuka dan bebas tafsir. Sebagai konsekuensi logis dari asumsi ketiga, yakni memandang 
sebuah segala sesuatu sebagai teks, maka (4) pandangan pascamodernisme memercayai apa yang disebut sebagai dekonstruksi. Pascamodernisme mencoba membaca ulang, melakukan penafsiran, kemudian meluluhlantakkan penafsiran tersebut dengan gugatan dan pertanyaan-pertanyaan kritis (Wardhani 2015).

\section{Kecenderungan-Kecenderungan dalam Pascamodernisme}

Banyak pakar berbicara lebih jauh tentang ciri-ciri pascamodernisme. Dalam artikel ini akan dikutip tiga pakar yang dianggap representatif, yakni Bertens (1995), Calhoun (1993) dan Ahmed (1992). Bagi Bertens (1995: 88) ada beberapa kecenderungan yang bersifatumumyang menjadi dasargerakan pascamodernisme. Dasar-dasar ini bisa disebutciri-ciri atau kerangka konseptual dari pascamodenisme itu sendiri. Pertama, segala 'realitas' merupaka konstruksi yang bersifat semiotis, artifisial dan ideologis. Kedua, adanya sikap ragu-garu (skeptis) sekaligus kritis terhadap segala bentuk pengetahuan dan keyakinan. Ketiga, sebuah realitas bisa ditangkap dengan pelbagai cara (pluralisme pandangan). Keempat, segala 'sistem' konotasi otonom dan tertutup, diganti dengan 'jaringan', 'relasionalitas' ataupun 'proses' yang senantiasa saling-silang dan bergerak dinamis. Kelima, segala unsur ikut saling menentukan dalam interaksi jaringan dan proses dalam interelasinya dengan bebagai aspek, tidak hanya sebagai oposisi biner dengan dua sisi saja. Keenam, segala hal harus dilihat secara holistik berbagai kemampuan lain selain rasionalitas, misalnya, emosi, imajinasi, intuisi, spiritualitas, dan sebagainya. Ketujuh, segala hal dan pengalaman yang selalu dimarginalisasi oleh pola ilmu pengetahuan modern dikembalikan ke tengah menjadi fream pemikiran.

Sementara Calhaoun (1993: 4) mengemukakan tujuh ciri pandangan pascamodern. Pertama, adanya ide atau gagasan yang menghendaki penghargaan yang sangat besar terhadap alam sebagai sebuah respon-kritis atas gerakangerakan modernisme yang cenderung mengeksploitasi alam dan menempatkan alam sebatas sebagai objek semata. Kedua, adanya ide yang menekankan urgensi bahasa dalam kehidupan manusia dengan segala kompleksitas dan analisanya. Poin ini merupakan antiteasa modernisme yang cenderung berjalan di atas kuasa tafsir yang dibuat oleh ' mesin birokrasi' ilmu pengetahuan. Ketiga, adanya ide besar untuk mengurangi kekaguman terhadap ilmu pengetahuan, kapitaslisme, dan teknologi yang muncul dari perkembangan modernisme. Keempat, terdapatnya ide penting inklusivitas dalam menerima tantangan agama lain atas agama dominan sehingga terbuka munculnya ruang-ruang yang lebih dialogis. Kelima, terdapat sikap yang lebih permisif dan terbuka untuk menerima ideologi dan juga agama lain dengan berbagai macam renik penafsirannya. Keenam, adanya ideide cemerlang yang berperan menjadi pendorong kebangkitan golongan yang tertindas serta minoritas yang secara sosial yang tersisihkan. Ketujuh, adanya ide tentang tumbuhnya kesadaran akan pentingnya interdependensi cara radikal dari semua pihak dengan cara yang dapat dan memungkinkan terpikirkan oleh manusia secara menyeluruh.

Ahmed dalam Postmodernism and Islam: Predicament and Promise (1992: 10-30) mencatat delapan karakter pascamodernisme yang menonjol. Pertama, 
pascamodernisme ditandai dengan muncul dan timbulnya pemberontakanpemberontakan secara kritis terhadap proyek-proyek modernitas. Pada konteks ini biasanya dibarengi dengan semakin memudarnya kayakinan dan juga kepercayaan pada agama yang bersifat transcendental atau fanatis sekaligus juga semakin diterimanya pandangan-pandangan kosmopotit dan pluralis serta juga mencuatkan pandangan akan relativisme sebuah kebenaran. Kedua, menjamurnya industri-industri media massa. Media massa menjadi semacam corong informasi. Pada konteks ini, batas antara produsen informasi dengan konsumen informasi sangat sumir dan menjadi sedemikian sulit untuk dibedakan. Ketiga, mulai munculnya radikalisme yang bersumber dan berakar dari nilai-nilai etnisitas dan juga keyakinan keagamaan. Kondisi ini terjadi disebabkan salah satunya oleh kecenderungan orang yang selalu mencari kebenaran dan jalan alternatif setelah sains dirasa tidak memberikan jawaban yang memuaskan dan sekaligus tidak bisa memasok kebenaran guna memecahkan problem manusia. Keempat, timbulnya sebuah kecenderungan-kecenderungan baru guna menemukan kembali identitas. Kelima, posisi wilayah perkotaan atau urban semakin menguat sebagai pusat kebudayaan. Keenam, sebagai akibat dari keterbukaan informasi, maka hal itu memicu pada semakin besarnya peluang bagi kelas-kelas sosial untuk mengemukakan pendapat secara lebih bebas. Ketujuh, adanya kecenderungan bagi tumbuhkembangnya adonan berbagai wacana yang berakibat pada sulitnya untuk mendefiniskan dan menempatkan sesorang secara ketat pada kelompok budaya tertentu secara eksklusif. Terakhir, bahasa-bahasa dan juga istilah yang digunakan dalam wacana postmodernisme kerap kali mengesankan kekeburan dan ketidakjelasan makna bahkan sekaligus inkonsist sehingga hal tersebut akhirnya melahirkan kesimpulan bahwa pascamodernisme sering atau bahkan selalu mengandung paradoks-paradoks.

Secara umum, pendapat-pendapat di atas bermuara pada: pertama, pascamodernisme memiliki tujuan untuk melakukan pendefinisian dan pembangunan ulang terhadap konsep-konsep yang sudah terbentuk dan mapan sebelumnya. Pascamodernisme meletakkan ketidakpercayaan dan keraguan akan segala hal sehingga hal itu mendasarinya untuk selalu bersikap kritis terhadap apa saja. Salah satu cara yang ditempuh tentu saja dengan mempertanyakan kembali konsep-konsep yang sudah mapan, meruntuhkannya, dan kemudian mendefiniskannya kembali.

Kedua, pascamodernisme selain memiliki watak selalu mempertanyakan dan menghancurkan definisi, konsep dan kemapanan lainnya, juga mencoba untuk mengangkat tema-tema yang pinggiran menjadi sentral. Subjek yang diangkat dalam pascamodernisme adalah subjek yang pinggiran, bukan sentrum, dan nyaris tidak diperhatikan sama sekali sebelumnya. Ketiga, pascamodernisme bekerja melalaui media keterbukaan informasi sehingga meruntuhkan dominasi dan patron komunikasi yang dianggap tidak ideal, artinya sekat komunikasi nyaris tidak ditemukan lagi. Keempat, terdapat sikap yang lebih permisif dan terbuka dalam menerima ideologi dan juga agama lain dengan berbagai macam renik penafsirannya. Kelima, adanya ide-ide cemerlang yang berperan menjadi 
pendorong kebangkitan golongan yang tertindas serta minoritas yang secara sosial yang tersisihkan. Keenam, segala unsur ikut saling menentukan secara interaktif dalam interaksi jaringan dan proses dalam interelasinya dengan bebagai aspek, tidak hanya sebagai oposisi biner dengan dua sisi saja.

\section{Pembentukan Identitas Baru Melalui Budaya Populer}

Salah satu corak pascamodernisme Ariel Heryanto tercermin dalam buku Identity and Pleasure: The Politics of Indonesian Screen Culture (2014) yang diterbitkan tahun 2014 dan diterjemahkan ke dalam Bahasa Indonesia menjadi Identitas dan Kenikmatan: Politik Budaya Layar Indonesia yang terbit tahun 2015 (Heryanto 2015). Buku ini merupakan studi panjang yang dilakukan sejak era Orde Baru tumbang. Objek yang dibidik dalam studi ini adalah bagaimana sebuah identitas 'baru' yang terbentuk dari sebuah kebudayaan populer yang banyak orang tidak menduganya, atau bahkan tidak ada yang menduga sama sekali. Budaya populer yang dimaksudkan di sini adalah budaya populer yang dibentuk dari budaya yang dilakukan oleh sebuah masyarakat secara massif dan secara spesifik yang berasal pada tontonan-tontonan layar seperti film, dan pertunjukan musik seperti K-Pop.

Pada bab-bab awal buku ini dikemukakan tiga alasan utama, mengapa studi ini diambil dan ditekuni. Pertama, keinginan untuk membandingkan kondisi antara pasca tumbangnya rezim Orde Baru dengan kondisi sebelum tumbangnya Orde Baru, terutama dalam kaitannya dengan-meminjam istilah Ariel 'hypernasionalisme' - sekaligus adanya kelupaan kolektif akan patahan sebuah sejarah yang terlupakan, dilupakan, atau cenderung dihapuskan. Alasan pertama ini lebih jauh dijelaskan oleh Ariel secara argumentatif bahwa sepsca Orde Baru tumbang seolah-olah banyak yang berubah. Tatanan kehidupan mengalami perubahan yang seolah-olah sangat signifikan, namun jika diletaah lebih dalam sesungguhnya tidak demikian. Sementara itu Orde Baru juga menanamkan tindakan-tindakan yang melegitimasi tafsir tunggal dengan cara memaksakan penyeragaman, dominasi budaya maskulin, sekaligus di lain pihak juga teror ketakutan akan asing. Tindakan tersebut ujungnya akan memunculkan apa yang disebut sebagai sentimen nasionalisme.

Sentimen nasionalisme ini terlihat setidaknya dalam film-film yang diproduksi di Indonesia yang hampir tidak pernah ditemui menempatkan tokoh asing atau bule sebagai tokoh yang protagonis. Mereka yang berkulit putih sebagai wujud paling kasat dari sentimen nasionalisme ini-selalu ditempatkan pada posisi lawan atau musuh yang antagonis. Dalam pada itu, kondisi tersebut berbaur dengan kelupaan kolektif atau manesia publik tentang patahan sejarah tentang 1965 atau bahkan jauh sebelum 1965 (era-era awal pergerakan) di mana orang-orang kiri memiliki andil dalam perjuangan kemerdekaan. Diakui atau tidak kelupaan kolektif ini salah satu penyebabnya adalah kokohnya bangunan narasi fiktif propaganda Orde Baru tentang gerakan kiri dan juga PKI. Pelbagai kampanye dan propaganda untuk membenci gerakan kiri dan PKI terus dilancarkan untuk melanggengkan 'kuasa ingatan' atas kekejaman dan kebengisan PKI (Heryanto 2008; Heryanto 1999). 
Di pihak lain, munculnya pelbagai macam media baru sekaligus menjadi instrumen yang mengubah tatanan sosial dan politik. Arus informasi menjadi mudah dan meruah. Informasi bisa diakses oleh siapa saja dan kapan saja. Bahkan, media sosial bisa menjadikan publik sebagai objek sekaligus subjek di saat yang bersamanaan. Kebenaran dan kebohongan informasi menjadi sumir. Munculnya pelbagai media baru, utamanya media sosial, menandai apa yang disebutmeminjam Istilah Redana-- sebagai revolusi digital dengan sifatnya yang melekat, yakni ilusi kerap menggantikan imajinasi, mimpi sering menggantikan akal sehat (Redana, Akal Sehat, 2015: 13). Ini adalah alasan kedua mengapa studi ini dilakukan.

Ketiga, adanya budaya populer. Utamanya yang dihasilkan dari media eletronik berbasis layar seperti film dan drama televisi. Ariel memaparkan bagaimana budaya layar ini memiliki kelindan yang kuat dengan pembentukan identitas dalam masyarakat Indonesia pasca tumbangnya Orde Baru.

Budaya populer yang dimaksudkan oleh Ariel pada kajiannya dibagi ke dalam dua definisi. ${ }^{1}$ Pertama, budaya populer yang berarti segala materi, film, musik, fesyen, acara televisi, yang diproduksi secara massal guna keperluan hiburan. Pada titik ini budaya populer diartikan sebagai produk industri yang bersifat komersil. Kedua, budaya populer diartikan sebagai produk non-industri. Produknya bisa berupa karya yang diproduksi secara independen, disebarkan secara mandiri sehingga bisa dikonsumsi oleh publik secara luas.

Pada bab-bab awal ketika berbicara tentang bagaimana sebuah identitas terbentuk, Ariel melihat ada sesuatu yang tidak pararel. Di satu sisi pasca keruntuhan Orde Baru, umat Islam secara politik melancarkan kegairahan yang luara biasa. Ada sebuah fenomena yang disebut sebagai kebangkitan politik Islam. Hal ini ditandai dengan semakin banyaknya panji-panji keislaman yang dibawa ke dalam arena perpolitikan. Setidaknya hal yang paling kasat adalah dengan ukuran banyaknya partai Islam yang muncul pasca tumbangnya Orde Baru. Hal yang seperti ini dalam catatan Ariel bukanlah sesuatu yang mengagetkan. Hal itu terjadi akibat langsung dari pola Orde Baru yang sangat 'represif' terhadap segala sesuatu yang berbau Islam. Maka, ketika rezim tersebut tumbang, luapan dan euforia itu menjadi-jadi, meledak, dan terkristalisasi dalam bentuk paling banal: membuat partai islam. Akhirnya sebagaimana kita ketahui jumlah partai Islam pasca reformasi menjadi sedemikian banyak. Jika pada era Orde Baru hanya terdapat tiga partai dan itupun yang benar-benar partia hanya satu yakni Golkar, sebab lainnya hanya bonsai, maka pada era pasca-Orde Baru jumlah partai semakin

1 Untuk keterangan lebih lanjut tentang budaya populer kajian terkini tentang budaya populer di Indonesia silakan rujuk Ariel Heryanto, 2018, 'Popular Culture and Identity Politics' dalam Routledge Handbook of Contemporary Indonesia, New York: Routledge. Juga Richard Fox, 2020, 'Pop Culture as Argument and Aspiration' dalam Bijdragen tot de Taal-, Land-en Volkenkunde vol 176. Aline Scott-Maxwell, 2020, 'K-pop Flows and Indonesian Student Pop Scenes: Situating Live Asian Pop Music in an 'Asian' Australia' dalam Media International Australia vol. 175; Asef Bayat, 2007. Making Islam democratic: social movements and the post-islamist turn, California, Stanford University Press. 
banyak. Demikian juga partai Islam, ia semakin banyak.

"Islamisasi politik" ini, tiba-tiba menjadi kelimpungan ketika harus berhadapan dengan sebuah pertanyaan, jika benar umat Islam adalah umat yang terbanyak dan mayoritas di Indonesia, mengapa partai politik Islam tidak bisa menang pemilu? Pada titik ini Ariel menawarkan sebuah gagasan bahwa ada pola yang tidak paralel tidak linier. Apa yang disebut sebagai Islamisasi politik tidak segendang sepenarian dengan artikulasi kultural keislaman masyarakat. Artinya ekspresi keberisalaman tidak senafas dengan islamisasi politik. Jika pada politik memunculkan fenomana islamisasi politik, maka sebaliknya di wilayah kultural dan kebudayaan memunculkan apa yang distilahkan oleh Ariel dengan "PostIslamisme". Apa itu yang dimaksud dengan istilah post-Islamisme? Yakni, sebuah ekspresi keberislaman yang sudah melampaui definisi-definisi keislaman yang selama ini-utamanya akibat produk Orde Baru yang memberlakukan segala sesuatu secara monlitik yang cenderung memberlakukan tafsir tunggal-semakin cair, sumir, beraneka, dan berwatak kosmopolit.

Apa yang menjadi pemicu lahirnya fenemena pembentukan identitas tersebut? Ariel mencatat beberapa hal, Pertama keterbukaan informasi dan menjamurnya media. Salah satunya media eletronik, termasuk film. Film dalam pandangan Ariel bukan merupakan sesuatu yang asal diproduksi begitu saja. Ia merupakan kristalisasi dan penjelamaan dari apa yang diinginkan dan didambakan masyarakat. Film tidak bisa dipandang sebelah mata dan didefinisikan hanya sebatas hiburan semata. Film, dalam pandangan Ariel, merupakan sesuatu yang serius, sehingga sangat laik dan menarik untuk dijadikan objek studi. Film diproduksi dengan proses kajian yang dilakukan secara serius. Selain itu, karena film diproduksi untuk kepentingan komersil, maka harus dibuat dengan cara yang serius, disajikan dengan cara yang serius, meskipun berisi hiburan. Film komersil berjalan di aras ideologi pasar dan sekaligus bersifat hanya meneguhkan apa yang sudah ada dan yang berlangsung di masyarakat.

Ariel melihat bahwa ada karakter yang tidak senafas dan cenderung terpecah belah pada umat Islam. Dalam mendiskusikan hal ini, Ariel meminjam teori Asef Bayat (2013) tentang fenomena pascaislamisme (post-islamism) yang dihubungkan dengan konteks kebudayaan. Ariel akhirnya sampai pada sebuah pemahaman bahwa ada sebuah generasi, di mana perempuan-perempuan muslim (muslimah) perkotaan di hampir seluruh wilayah Indonesia, telah memasuki era post-islamisme. Ciri yang paling menonjol dari generasi ini adalah mereka ingin tetap bisa menikmati selera-selera kebudayaan serta ekspresi kemerdekaan diri di satu kutub dengan tanpa mengorbankan keimanannya sama sekali di kutub lain (Heryanto: 2015, 53).

Ariel menjadikan film Ayat-Ayat Cinta sebagai salah satu objek studi. Baginya film ini dapat dijadikan referensi yang tepat untuk mengambarkan fenomena post-islamisme yang menjangkiti generasi muda muslimah perkotaan. Film yang disutradarai Hanung Bramantyo ini dirilis pada tahun 2008. Film Ini menjadi titik tolak kebangkitan film islami. Meskipun kehadirannya tergolong berimbang antara menuai puian dan cibiran, namun penting untuk dicatat bahwa film Ayat- 
ayat Cinta ini merupakan film islami denga rekor penonton yang cukup dahsyat (ditonton sebanyak 4,5 juta).

Ariel melihat adanya pertempuran sinematis yang terjadi pada masyarakat post islamisme dalam upaya mencari dan mendefinisikan diri untuk menjadi muslim yang baik dan ideal. Sosok Fahri sebagai pemeran utama film AyatAyat Cinta menjadi representasi ideal dan dambaan muslimah indoneia saat itu. Sosok Fahri yang tampan, akademik, klimis, berprestasi, berpendidikan tinggi, menggiring pada pendefinisian identitas baru bahwa menjadi muslim tidak harus selalu bergamis, berpeci, bersarung, keluar-masuk masjid, kumal dan citra negatif lain yang telah dibentuk dan didefinisikan oleh Orde Baru.

Pada kajian selanjutnya, Ariel memusatkan perhatian pada fenomena yang tejadi pada 1965 dan 1966. Tahun-tahun ini diakui oleh banyak peneliti, termasuk Ariel, sebagai tahun yang sangat berpengaruh dalam pembentukan identitas bangsa Indonesia di hampir semua bidang: politik, pendidikan, kebudayaan, ekonomi, dan lain sebagainaya. Fokus Ariel dalam kajian ini adalah bagaimana menguak praktik doktrinasi dan indoktrinasi melalui film.

Proses doktrinasi melalui film kaitannya dengan 1965 dan 1966 dilakukan oleh rezim Orde Baru dalam upaya untuk menanamkan kebencian terhadap kelompok tertentu. Ariel mencatat peristiwa dimulai pada 15 April 1969 saat Komkamtib menegeluarkan proyek pembuatan film. Dari proyek ini, rezim yang berkuasa saat itu berharap film-film propaganda bisa diproduksi yang dikonsumsi secara massal. Dua film yang memaliki agenda sentimen dan kebenian terhadap kelompok tertentu adalah film Janur Kuning (1979) dan Serangan Fadjar (1981). Dua film tersebut mencoba meng-hero-kan sosok Soeharto sebagai pahlawan dan tokoh yang berperan penting dalam revolusi 1965 di satu sisi, sekaligus menegasikan dan memojokkan PKI dan kelompok kiri sebagai pihak antagonis yang jahat, bengis, dan bersalah di sisi lain. Propaganda ini berlanjut dan memuncak setelah dikelurakannya film Gerakan 30 September (G30S), yang dari judulnya saja sudah sangat propaganda karena belakangan ditambahi dengan PKI menjadi G30S/PKI dengan harapan ingatan publik tergiring pada "PKI" yang ada dalam judul film tersebut. Sukses film G30S disusul dengan propaganda-propaganda film lainnya untuk menebarkan kebencian dan sentimen kelompok. Film-film itu antara lain Operasi Sisa-sia PKI Blitar Selatan (1986) dan juga Djakarta 1966 (1982).

Proses-proses doktrinasi yang dilakukan oleh Orde Baru terbukti sukses dan bahkan bertahap sangat lama. Sentimen terhadap PKI dan kelompok kiri masih kental dirasakan hingga sampai saat ini. Tahun 2019 saja, di saat usia reformasi telah memasuki usia 11 tahun, sisa-sisa kebencian dan sentimen tehadap PKI masih bisa dirasakan, bahkan beberapa tahun lalu Presiden Jokowi menyelenggarakan nonton bareng film PKI atas prakarsa oleh Panglima TNI Jenderal Gatot Nurmatyo saat itu.

Selalu adalah perlawanan terhadap proses doktrinasi yang terjadi. Skala dan dan bentuk perlawan tehadap propaganda dan doktrinasi tersebut memiliki varian yang berbeda-beda. Salah satu manarik perhatian Ariel adalah perlawanan melalui film-film indie. Film-film tersebut mencoba meruntuhkan praktik doktrinasi yang 
selama ini dilakukan oleh Orde Baru. Film-film indie yang diamati Ariel antara lain Puisi Tak Terkuburkan (1999) Act of Killing (2013) dan The Look of Silence (Senyap) (2015). ${ }^{2}$ Film-film tersebut mencoba meruntuhkan propaganda Orde Baru tentang peristiwa 1965. Sayangnya, dalam pandangan Ariel film-film tersebut dirasa cukup monoton. Kemonotonan ini dalam pandangan Ariel disebabkan oleh kelapaan film-film tersebut dalam menghadirkan konteks-konteks tertentu seperti perang dingin, ekonomi-politik global, persaingan di tingkat elit politik, dan rasisme. Sebaliknya film-film tersebut hanya berfokus pada penyiksaan, kekejian dan pelanggaran kemanusiaan. Meskipun demikian dalam pandangan Ariel ada satu film indie yang melakukan indoktrinasi dan merupakan kekecualian dari monotonitas film-film indie di atas. Film indie yang dimaksudkan adalah Mass Grave yang disutradari oleh Lexi Lambradeta.

Dampak lain dari propaganda peritsiwa 1965-1966, selain kekerasan dan kekejaman, adalah pelanggaran Hak Asasi Manusia (HAM). Propaganda yang sama, namun dalam konteks yang berbeda dilakukan terhadap orang-orang beretnis Tionghoa. Rezim Orede baru dalam pandangan Ariel melabeli dan memperlakukan orang-orang Tionghoa secara tidak adil dan diskriminatif. Tercatat sejumlah kebijakan yang tidak memihak mereka, seperti aturan penggatian nama, merupakan wujud nyata dari kebijakan yang tidak adil. Mereka yang telah lama berdiam diri dan menetap di Indonesia diperlakukan oleh Orde Baru tidak lebih sebatas 'tamu' atau bahkan dianggap orang asing. Namun, yang menarik dalam pandangan Ariel, pemerintah Orde Baru memberlakukan kebijakan yang ambivalen dan paradoks. Jika dalam politik warga Tionghoa dan keturunan Tionghoa diperlakukan tidak adil, sebaliknya di di bidang eknomi, Orde Baru memberikan hak-hak yang istimewa pada elit-elit Tionghoa. Dalam bahasa Ariel, etnis Tionghoa memiliki dua atribut sekaligus: sebagai kambing hitam dan juga sapi perah di satu sisi.

Kambing hitam yang dimaksudkan Ariel ialah etnis Tionghoa sering menjadi sasaran dan alamat kesalahan jika terjadi kekacauan politik nasional. Sementara sapi perah adalah kondisi yang menjadikan elit Tionghoa sebagai pihak untuk memperlancar bisnis sebab dinilai berbakat dalam berdagang. Kondisi ini dalam pengamatan Ariel bukan lahir begitu saja. Ini merupakan warisan kolonialisme yang memiliki kebijakan membagi penduduk menjadi tiga jenis: Eropa, Timur asing (vremdee osterlingen) dan pribumi. Selain itu etnis Tionghoa sering dikaitpautkan dengan bangsa Cina daratan yang diasumsikan memiliki hubungan erat dengan partai komunis Cina.

Di dalam film-film yang diproduksi di Indonesia, etnis Tionghoa selalu menempati posisi yang marjinal dan terpinggirkan. Istilah yang dipakai adalah

2 Untuk informasi lebih mendalam tentang kajian film ini periksa Intan Paramaditha, 2013, 'Tracing Frictions in The Act of Killing' dalam Film Quarterly, Vol. 67, No. 2. Juga Ariel Heryanto, 2014, 'Great and Misplaced Expectations' dalam Critical Asian Studies, Vol. 46 No. 1. dan Ariel Heryanto, 2018, 'Decolonising Indonesia, Past and Present' dalam Asian Studies Review, Vol. 42 No.4. 
Tionghoa (dengan tanda coret), untuk menggambarkan bahwa sebetunya etnis tersebut eksis, namun keberadaannya dinegasikan. Uniknya, film pertama yang dijadikan tonggak menggeliatnya sinema di Indonesia, yakni film darah dan doa, diproduksi atas bantuan seorang pengusaha Tionghoa. Baru kemudian ketika film-film seperti Ca Bau Kan (2002) dan Gie (2005), etnis Tionghoa muncul dan mendapatkan tempat di dunia perfilman Indonesia. Dalam pandangan Ariel, ini adalah tanda bahwa propaganda kebencian terhadap etnisitas tertentu mulai runtuh seiring runtuhnya Orde Baru (Heryanto 2008a).

Setelah memfokuskan kajian pada film, Ariel mecoba mengalihkan perhatiannya pada K-Pop dan budaya jalanan kelas bawah, utamanya dalam konteks kontestasi pemilihan umum tahun 2009. Khusus untuk persoalan K-Pop, tampak Ariel ingin mengetengahkan kesimpulan bahwa generasi muda adalah peserta aktif dalam merumuskan identitas masyarakat Indonesia. Kesimpulan ini dasarkan pada temuannya bahwa ia menemukan tren yang semakin menjamur ketika fesyen muslimah perkotaan menjadi lahan bisnis yang semakin merajai pasar. Ariel mencatat bahwa dominasi K-Pop bukan sekedar hura-hura tanpa arti dan tidak memiliki makna sama sekali. Ia bukanlah anak-anak muda yang krisis identitas terhadap 'budaya adiluhung' yang dimiliki Indonesia. Fenomena ini merupakan fenomena kompleks yang tidak lahir begitu saja dari ruang kosong. Bagi Ariel, fenomena kegandrungan kelas menengah perkotaan terhadap K-Pop, memiliki hubungan yang sangat erat dengan konsolidasi kelas menengah, sentimen anti Tionghoa, dan Post Islamisme yang terjadi dan dijelaskan pada bagian-bagian sebelumnya (Heryanto 2015: 251).

K-Pop dalam pandangan Ariel bisa menjadi titik tolak untuk melihat adanya usaha-usaha yang dimaksdukan untuk menggoyang status quo yang dibentuk oleh kaum konservatif di Indonesia. Dalam pandangan Ariel, terdapat fenomena menarik ketika muslimah muda perkotaan berjingkarak-jingkrak menyambut kedatangan bintang pujaannya asal Korea. Demam Korea bagi Ariel bermakna politis. Faktor utama yang menyebabkan demam K-Pop bukan semata alasan kedekatan budaya antara Indonesia dengan Korea Selatan, namun juga adanya faktor hibriditas budaya yang meleburkan batas-batas apa yang disebut sebagai Barat dengan Timur. Faktor ini yang menyebabkan muslimah-muslimah kelas menengah Indoneia menjadi gandrung dengan K-Pop dan K-Drama. Dalam bahasa yang ringkas apa yang mereka lakukan sesungguhnya sedang membentuk identitas dengan berlandaskan 'kenikmatan'.

\section{Merayakan Iman tanpa Ketinggalan Kenikmatan}

Studi yang dilakukan Ariel Heryanto ini mengungkapkan bahwa ada pemberontakan-pemberontakan pada kemapanan definisi yang sebelumnya telah diberikan atau bahkan bersifat nyaris seluruhnya 'given by regime' yang dilakukan oleh Orde Baru. Pemerintahan yang berkuasa leih daru tiga dekade ini membuat kebijakan-kebijakan yang monolitik terhadap hampir seluruh bidang kehidupan sosial politik penduduk Indonesia. Akibatnya sebuah definisi dan konsep telah dibuat dan dibentuk dari atas dan dipaksa untuk diterapkan sampai tingkat 
masyarakat paling bawah sekalipun. Ini berarti, ada pola penyeragaman atau yang sering dikenal dengan istilah tafsir tunggal. Ini juga terjadi dalam konteks pendefinisian identitas. Siapa yang disebut sebagai masyarakat Indonesia, bagaimana ciri-cirinya, dan seterusnya dan sebagainya telah dibakukan dalam kategori-kategori tertentu yang bersifat politis dan cenderung reduksionis. Pada posisi ini lahir apa yang kemudian diistilahkan sebagai pribumi dan non-pribumi sebagai anak sah dari pola pikir reduksionis tersebut. Padahal, bangsa Indonesia adalah bangsa yang multikutur sekaligus kosmopolit (Alniezar 2017). Watak ini, utamanya multikulturalisme, tidak bisa begitu saja direduksi menjadi sesederhana yang sebagaimana didefinisikan dan dikategorikan oleh Orde Baru.

Timbulnya perlawanan, pemberontakan dan gugatan tentang definisi apa dan siapa yang disebut sebagai bangsa Indonesia yang berwujud dalam bentuk tindakan seperti pilihan untuk menyukai K-Pop dan K-Drama atau bahkan pendefinisian ulang tentang menjadi sosok muslim adalah indikasi dari semakin memudarnya kayakinan dan kepercayaan pada agama. Ariel menyatakan:

\begin{abstract}
“Bagi sebagian besar orang di negeri dengan jumlah Muslim terbesar di dunia, terutama bagi kaum mudanya, ketaatan beragama dan modernitas sama menariknya dan tidak selalu keduanya saling bertentangan. Bagi mereka, ketaatan beragama dan konsumsi budaya populer tersedia sebagai pilihan ketimbang hal yang hanya bisa dipilih salah satu saja. Sementara di masa lalu orang memandang ketaatan dan hiburan sebagai hal yang tak cocok satu sama lain, muslim generasi baru menemukan cara (sekalipun banyak yang menadangnya sebagai cara yang dangkal) untuk mendamaikan hal-hal yang secara tradisional dipandang sebagai bertolak belakang, yang membuat mereka mampu terlibat dengan agama dan budaya populer secara bermakna dan sungguh-sungguh" (Heryanto 201: 47).
\end{abstract}

Dalam konteks ini, Ariel mencatat adanya kecenderungan-kecenderungan baru guna menemukan kembali identitas. Identitas lama dihancurkan, dirumuskan ulang dan kemudian didefinisikan kembali. Dalam buku Identitas dan Kenikmatan: Politik Budaya Layar Indonesia ini upaya pendefinsian sebagai muslim dan juga sebagai manusia Indonesia coba dirumuskan ulang. Definisi lama yang mengurung muslim sebagai manusia yang taat, kolot, dan kaku, tidak pantas untuk bersenangsenang dan lain sebagainya dihancurkan dan dirmuskan ulang. Dalam konteks ini Ariel mengatakan:

\begin{abstract}
"Salah satu pendapat pokok yang ingin diajukan adalah adanya tanda-tanda awal terbentuknya gugusan muslim modern di Indonesia. Kelompok ini cenderung berusia muda dan berasal dari kelas menengah. Mereka beraspirasi untuk mendefinisikan ulang arti menjadi muslim, secara bertolak belakang dengan muslim ideal yang direkomendasikan oleh otoritas keagamaan lama yang berada di lembaga-lembaga mapan atau elite politik saat ini" (Heryanto 2015: 49).
\end{abstract}

Ariel melihat usaha itu dengan mefokuskan pengamatannya pada budayabudaya yang berbasis layar yang meliputi film, K-Pop, K-Drama, dan budaya populer politik jalanan. Dalam pandangan Ariel, melalui film Ayat-Ayat Cinta sosok muslim masa kini adalah sosok yang dicitrakan sebagai yang bersih, klimis, 
modis, akademis, rajin, dan bekerja keras. Menjadi muslim tidak terkungkung pada sebatas lokus-lokus 'ubudiyah' seperti masjid, musala, dan majlis taklim. Dalam pandangan Ariel, sosok Fahri dalam film Ayat-Ayat Cinta mencitrakan dan menawarkan definisi baru bahwa menjadi muslim yang saleh itu tidak harus bergamis dan berjenggot panjang. Fahri adalah sosok cerdas, organisatoris yang tidak kuper dan pada saat yang bersamaan ditaksir oleh empat perempuan sekaligus. Meminjam istilah Dwifatma (2017) Fahri adalah sebuah jalan tengah yang menawarkan formula bagaimana menjadi mulsim yang saleh di satu kutub dengan tanpa ketinggalan zaman sama sekali di kutub lain. Ariel mengatakan: “.. orang Indonesia yang tinggal di perkotaan berusaha untuk berakrobat dengan menggunakan tiga bola sekaligus: menjadi Muslim taat [..], menjadi warga negara yang terhormat [..], sekaligus menjadi anggota komunitas produsen dan konsumen global" (Heryanto 2015: 75-76)

Ariel mengungkapkan bahwa penulis novel Ayat-ayat Cinta, Habiburrahman El-Shirazy, menulis novel berdasarkan pengamatannya pada kehidupan mesir kala ia menjadi mahasiswa. Tujuan utamanya hanya ingin mendakwahkan Islam. Dengan tujuan yang global tersebut sangat sulit rasanya untuk mengatakan bahwa Novel tersebut ditulis dengan terlebih dahulu memikirkan dengan serius pandangan-pandangan pascamodernisme. Ariel menulis "Penulis Habiburrahman El-Shirazy, seorang muslim yang taat, mengaku menulis cerita ini berdasarkan pengematannya mengenai kehidupan di Mesir ketika ia menjadi mahasiswa di sana dengan 'sebuah tujuan untuk mendakwahkan islam'" (Heryanto 2015: 84)

Dalam buku Identitas dan Kenikmatan: Politik Budaya Layar Indonesia ini, Ariel mencoba mengangkat subjek-subjek kecil yang selama ini tidak pernah mendapatkan perhatian serius, jika tidak ingin dikatakan tidak mendapatkan perhatian sama sekali. Ariel mengangkat film komersil dan juga film dokumenter, atau bahkan pengamatannya terhadap fenomena K-Pop dengan tariannya. Itu semua membuktikan bahwa Ariel sedang ingin melakukanupaya sentralisasi subjek yang awalnya ada di pinggiran. Ini adalah ciri khas pandangan pascamodernisme yang tidak selalu berfokus pada subjek besar semata, namun lebih dari itu justru mengangkat yang kecil-kecil dan terlihat sepele namun memiliki makna bahkan sangat penting keberadaanya.

Bagi Ariel, budaya populer merupakan objek pinggiran yang sering dikesampingkan dalam kajian dunia akademis. Hal itu disebkan karena adanya anggapan bahwa terdapat hubungan 'mesra' yang tidak tahu malu antara budaya pop dengan dunia industry yang hanya sibuk mengejar laba. "Budaya populer sulit untuk mendapatkan status terhormat dari lingkungan elite yang beragam karakter politiknya. Kaum elit berusaha merendahkan budaya populer dengan dengan menggunakan istilah budaya massa." (Heryanto 2015: 24)

Lebih jauh, untuk mengukuhkan argumentasinya yang menyimpulkan bahwa kajian akademik masih meminggirkan budaya populer, Ariel menulis dalam sebuah tulisan yang lain bertajuk Pop Culture and Competing Identities. Di dalam tulisan tersebut dikemukakan bahwa pandangan yang canderung menempatkan budaya populer sebagai objek pinggiran dalam dunia akademik. Ariel mencatat: 
“......tiga alasan mengapa minat kaum akademis pada bidang ini (budaya populer) sangat sedikit dan lamban, yaitu ekspansi industrialisasi di wilayah ini (budaya populer) baru terjadi belakangan, kuatnya sebuah paradigma dominan kajian-kajian Indonesia di sepanjang sejarahnya - seperti kungkungan isu masalah pembangunan Negara bangsa dan modernisasi--, serta bias maskulin pada dunia akademis pada umumnya" (Heryanto 2008b: 6-7).

Dalam konteks pendefinisian identitas, Ariel melihat bahwa pemicu utama perlawanan terhadap doktrinasi Orde Baru yang mendikte untuk bersikap sentimen dan benci terhadap sebuah kelompok dan etnis salah satunya dimotori perlawanan yang dilakukan via media massa. Dalam konteks ini, yang dimaksud adalah media yang bisa diproduksi dan dikonsumsi oleh khalayak.

Ariel mengistilahkan proses indoktrinasi ini dengan pertempuran sinematis. Betapa film-film propaganda anti PKI yang dilanggengkan melalui program pemerintah dilawan secara terus menerus oleh film-film, baik yang indie maupun yang komersil. Selain itu, media massa yang dan juga media sosial yang semakin menjamur menjadikan informasi sebagai barang yang sangat mudah didapatkan. Masyarakat pada posisi ini bisa menduduki dua posisi sekaligus: pemasok atau produsen dan sekaligus konsumen. Media massa menjadi semacam corong informasi. Gerakan-gerakan sosial semacam perlawanan terhadap kemapanan, dalam konteks ini pendefinisian ulang identitas, menjamur salah satunya sangat dipengaruhi oleh media massa. Film-film perkawanan diproduksi, diedarkan, dan dibagikan secara luas. Posisi ini yang menjadikan perlawanan tersebut bisa terus bergeliat. Ini adalah watak pandangan pacsamodernisme ketiga yang menggunakan media massa sebagai instrumen perlawanan. Ariel mengatakan:

“Perubahan belakangan ini dalam mediascape di Indonesia tidak unik dan tak terpisah dari apa yang sedang terjadi di seluruh dunia. Pada decade kedua abad ini, menjadi amat jelas bagaimana media barutelah campur tangan dalam membentuk ulang kehidupan sosial kita di seluruh dunia, dalam berbagai kadar.....Jaringan televise lokal taka da semasa kejatuhan rezim orde baru, tapi satu decade kemudian sekitar 150 jaringan telah beroprasi di seluruh negeri. Pada saat buku ini disiapkan pada pertengahan tahun 2013, jumlahnya meningkat lagi hingga 415" (Heryanto 2015: 13-15).

Di lain pihak, kemunculan media sosial dikatakan sebagai menjadi sarana yang sangat efektif untuk mempersempit ruang dan memangkas jurang komunikasi yang selama ini cenderung berpola atas-bawah sebagaimana yang terjadi pada saat Orde Baru berkuasa. Rakyat kecil atau siapa saja bisa bebas menyampaikan perndapat kepada pejabat, baik pemerintah daerah maupun pusat melalui media sosial yang mereka miliki. Orang bisa kapan saja me-mention akun media sosial Presiden atau lembaga Negara. Segala keluhan dan macam-macam aduan masuk dan bercampur aduk di sana.

Pada kondisi yang demikian terbuka itu, maka konsekuensi yang lahir kemudian adalah adanya kecenderungan bagi semakintumbuh kembangnya berbagai wacana yang berakibat pada sulitnya untuk mendefiniskan dan menempatkan sesorang secara ketat pada kelompok budaya tertentu secara 
eksklusif. Pendefinisian sesuatu semakin sumir dan bahkan saling tumpang tindih dan tidak jelas. Dalam konteks ini pendefinisian apa artinya menjadi Indonesia, apakah ia dibatasi oleh identitas baku yang telah dirumuskan oleh Orde Baru atau ada alternatif pemaknaan lain yang lebih baru, lebih segar, lebih terbuka dan tidak jumud? Pertanyaan tentang siapa manusia Indonesia sekaligus identitas otentik manusia indonesis seperti apa sepasca Orde Baru tumbang menjadi sedemikian riuh. Banyak kekuatan yang berlomba untuk saling mengisi 'kekosongan kekuasaan' tersebut. Masing-masing kekuatan beradu kuasa, saling talik ulur guna meneguhkan dominasi yang pada gilirannya diharapkan bisa menjawab pertanyaan besar tentang identitas menjadi manusia Indonesia.

Keberadaan media-media tersebut, bukan hanya berhenti sebatas untuk menjadi sarana komunikasi virtual saja, namun juga menjadi arena pertempuran ideologi, politik dan ekonomi bagi berbagai golongan, ras, gender, bahkan kelas sosial. Di saat yang bersamaan, dalam buku Identitas dan Kenikmatan: Politik Budaya Layar Indonesia ditemukan bahwa media baru juga memiliki kuasa untuk ikut campur dalam konteks penataan kehidupan sosial. Ariel menulis bahwa dunia yang terbentuk adalah dunia yang mengubah: "cara-cara di mana identitas secara tradisional telah dibentuk; kelas sosial dan, keluarga inti, serikat pekerja, perasaan guyub, dan/atau lokasi geografis, seluruhnya itu menjadi sangat cair dan tidak lagi menjadi pokok dalam menentukan siapa 'kita' sebagai anggota dari kelompok sosial itu" (Heryanto 2015: 15).

Sikap terbuka dalam menafsirkan sebuah ideologi sebagaimana yang terjadi dalam menafsirkan gerakan kiri dan PKI yang dilakukan dengan cara menciptakan tontonan alternatif melalui film indie yang bertema 1965 juga merupakan bukti selanjutnya dari watak dan pandangan pascamodernisme yang menolak cara pandang yang bersifat monolitik. Ini merupakan ciri keempat pandangan pascamodernisme.

Dalam pada itu, ada upaya untuk terus bergerak menemukan identitas menjadi bangsa Indonesia dengan mengangkat isu PKI dan juga Tionghoa yang notabene merupakan minoritas adalah wujud nyata dari ciri pandangan pascamodernisme yang mengatakan bahwa pascamodernisme ditandai dengan adanya ide-idecemerlang yang berperan menjadi pendorongkebangkitan golongan yang tertindas serta minoritas yang secara sosial yang tersisihkan. Dua kelompok ini, Kiri (PKI) dan Tionghoa dalam bahasa Ariel adalah minoritas yang oleh rezim sebelumnya disisihkan dan bahkan dicoba untuk dihapus keberadaannya. Ariel melambangkannya seperti ini: PKI dan Tionghoa (dengan striketrough). Ariel menulis: "sebuah proyek untuk memurnikan Indonesia dan film Indonesia dengan membersihkannya dari pelbagai unsur yang memperkayanya (yang selama ini telah menjadi bagian tak terpisahkan darinya), merupakan sebuah upaya untuk memenggal bagian tubuh sendiri, jika tidak bisa dikatakan bunuh diri." (Heryanto 2015: 240).

Pandangan-pandangan yang bersifat opositif atau bentuk-bentuk yang berlawanan dan cenderung berpola oposisi biner dalam hemat pascamodernisme ditolak. Dalam konteks buku Identitas dan Kenikmatan: Politik Budaya Layar Indonesia 
ini pandangan tersebut misalnya tercermin dalam penolakan terhadap pandangan yang selama ini sangat tersebar luas antara Islam melawan kapitalisme. Artinya menjadi muslim harus menghindari budaya kapitalisme yang dipandang peyoratif dan buruk. Dalam buku ini, justru Ariel menemukan pola dan gejala bagaimana menjadi muslim yang tetap eksis di era kapitalisme dan budaya konsumtif. Muslimah perkotaan tetap meneguhkan identitasnya sebagai muslimah dengan tanpa menegasikan kecintaan dan kegandrungan mereka pada K-Pop, K-Drama, dan budaya populer lainnya. Bahkan, dalam konteks film, muslim yang ideal adalah pencitraan yang sebagaimana digambarkan pada sosok Fahri (tokoh utama film Ayat-Ayat Cinta) yang tampan, modis, fashionable, tidak kolot, akademis, dan organisatoris. Ini merupakan pandangan pascamodernisme yang juga ditemukan dalam buku Identitas dan Kenikmatan: Politik Budaya Layar Indonesia. Ariel mengatakan:

“.....persoalan apa artinya menjadi modern sama pentingnya (jika tak lebih penting) dengan pertanyaan apa artinya menjadi muslim di balik semua perdebatan yang muncul dari kecenderungan baru ini. Kaum muslim muda berusaha untuk berpartisipasi secara penuh di dunia modern tanpa melepaskan keimanan mereka" (Heryanto 2015: 47).

\section{Simpulan}

Corak dan konstruksi pascamodernisme dalam kajian Ariel sebagaimana telaah dalam artikel ini meliputi pertama, memiliki tujuan untuk melakukan pendefinisian dan pembangunan ulang terhadap konsep-konsep yang sudah terbentukdanmapansebelumnya.Pascamodernismemeletakkanketidakpercayaan dan keraguan akan segala hal sehingga hal itu mendasarinya untuk selalu bersikap krtis terhadap apa saja. Kedua, Pascamodernisme mencoba untuk mengangkat tema-tema yang pinggiran menjadi sentral. Ketiga, Pascamodernisme bekerja melalui media keterbukaan informasi sehingga meruntuhkan dominasi dan patron komunikasi yang dianggap tidak ideal. Keempat, terdapat sikap yang lebih permisif dan terbuka dalam menerima ideologi dan juga agama lain dengan berbagai macam renik penafsirannya. Kelima, adanya ide-ide cemerlang yang berperan menjadi pendorong kebangkitan golongan yang tertindas serta minoritas yang secara sosial yang tersisihkan. Keenam, segala unsur ikut saling menentukan secara interaktif dalam interaksi jaringan dan proses dalam interelasinya dengan bebagai aspek, tidak hanya sebagai oposisi biner dengan dua sisi saja.

Pascamodernisme adalah gerakan kebudayaan pada umumnya, yang dicirikan oleh penentangan terhadap totalitarianisme, serta universalisme, serta kecenderungan ke arah keanekaragaman, ke arah melimpah ruah dan timpang tindihnya berbagai citra, gaya, sehingga menimbulkan fragmentasi, kontradiksi, dan pendangkalan. Asumsi dasar yang dibangun oleh Pascamodernisme adalah Asumsi dasar yang dibangun oleh pascamodernisme adalah Pertama, kepercayaan akan kedaulatan yang otonom yang dimiliki oleh setiap indovidu. Kedua, pascamodernisme meyakini adanya genealogi yang menyatakan bahwa ilmu penegathuan datang dan dibuat dengan berdasarkan kepentingan manusia 
yang tentu saja dibatasi oleh ruang dan waktu. Ketiga adanya kepercayaan akan pendekatan tekstualisme. Artinya segala sesuatu diperlakukan sebagai teks yang terbuka dan bebas tafsir. Keempat, sebagai konsekuensi logis dari asumsi ketiga, yakni memandang sebuah segala sesuatu sebagai teks, maka pandangan pascamodernisme memercayai apa yang disebut sebagai dekonstruksi. Artinya pascamodernisme mencoba membaca ulang, melakukan penafsiran, kemudian meluluhlantakkan penafsiran tersebut dengan gugatan dan pertanyan-pertanyaan kritis.

Kedua, dalam buku Identitas dan Kenikmatan: Politik Budaya Layar Indonesia Ariel menggunakan epistemologi pascamodernisme yang cara kerjanya ditempuh dengan meruntuhkan definisi yang sudah ada, mempertanyakannya kembali dan kemudian memberikan tawaran alternatif jawaban dan definisi yang baru. Dalam konteks ini isu yang diangkat adalah soal pemaknaan akan identitas keindonesiaan utamanya yang menyangkut pemaknaan menjadi muslim Indonesia, bagaimana identitas tentang keminoritasan, baik ras maupun golongan tertentu (Kiri dan PKI), dan juga sekaligus ekspresi memilih kenikmatan dengan sekaligus meneguhkan dan membangun identitas dalam koteks kegandrungan muslimah kelas menengah terhadap K-Pop dan K-Drama dan budaya populer berbasis layar lainnya. Dalam buku ini Ariel mencoba merumuskan ulang bagaimana menjadi muslim yang taat, bagaimana menjadi warga negara yang baik sekaligus di saat yang bersamaan tetap eksis menjadi anggota komintas produsen dan konsumen global. 


\section{Daftar Pustaka}

Ahmed, Akbar S. 1992. Postmodernism and Islam: Predicament and Promise. New York: Routledge.

Alniezar, Fariz. 2017. “Indonesia Yang Membelum.” Basabasi 2017. Retrieved March 3, 2019 (https:/ / basabasi.co/indonesia-yang-membelum/).

Baudrillard, Jean. 1994. Simulacra and Simulation. Michigan: The University of MIchigan.

Bayat, Asef. 2007. Making Islam democratic: social movements and the postislamist turn, California, Stanford University Press.

Bayat, Asef. 2013. "Post-Islamisme at Large." Pp.3-34 in Post-Islamism The Changing Faces of Political Islam.

Bertens, Hans. 1995. The Idea of the Postmodern: A History. Vol. 69. New York: Routledge.

Butler, Christopher. 2002. Postmodernism: A Very Short Introduction. New York: Oxford University Press.

Calhoun, Craig. 1993. "Postmodernism as Pseudohistory." Theory, Culture E Society 10(1):75-96. doi: 10.1177/026327693010001004.

Dator, Jim. 2004. “Islam, Postmodernism and Other Futures: A Ziauddin Sardar Reader." Futures 36(1):115-26. doi: 10.1016/s0016-3287(03)00137-x.

Dwifatma, Andina. 2017. "Merumuskan Dan Menikmati Identitas." Jurnal Ruang 2017. Retrieved March 23, 2019 (https://ruang.gramedia.com/ read/1497868344-melongok-identitas- kaum-muda-kota-lewat-layar).

Fox, Richard. 2020, Pop Culture as Argument and Aspiration dalam Bijdragen tot de Taal-, Land-en Volkenkunde vol 176

Hassan, Ihab. 1985. “The Culture of Postmodernism." Theory, Culture E Society 2(3):119-31. doi: 10.1177/0263276485002003010.

Heryanto, Ariel. 1999. “Where Communism Never Dies: Violence, Trauma and Narration in the Last Cold War Capitalist Authoritarian State." International Journal of Cultural Studies 2(2):147-77. doi: 10.1177/136787799900200201.

Heryanto, Ariel. 2008a. "Citizenship and Indonesian Ethnic Chinese in Post1998 Films." Pp. 70-92 in Popular Culture in Indonesia: Fluid Identities in PostAuthoritarian Politics, edited by A. Heryanto. New York: Routledge.

Heryanto, Ariel. 2008b. "Pop Culture and Competing Identities." Pp. 1-36 in Popular Culture in Indonesia Fluid identities in post-authoritarian politics, edited by A. Heryanto. New York: Routledge.

Heryanto, Ariel. 2014. Identity and Pleasure: The Politics of Indonesian Screen Culture. Singapore: NUS Press.

Heryanto, Ariel. 2014, Great and Misplaced Expectations dalam Critical Asian Studies, vol. 46 No. 1.

Heryanto, Ariel. 2015. Identitas Dan Kenikmatan: Politik Budaya Layar Indonesia. Jakarta: Kepustakaan Populer Gramedia. 
Heryanto, Ariel. 2018, Popular Culture and Identity Politics dalam Routledge Handbook of Contemporary Indonesia, New York: Routledge.

Heryanto, Ariel. 2018, Decolonising Indonesia, Past and Present dalam Asian Studies Review, vol. 42 No.4.

Jameson, Fredric. 1997. Postmodernism, or, the Cultural Logic of Capitalism. Duke: Duke University Press.

Lyotard, Jean-Francois. 1984. “Postmodern Condition: A Report on Knowledge."

Mazer, Sharon. 1998. From Acting to Performance: Essays in Modernism and Postmodernism (Review). Vol. 50.

Paramaditha, Intan. 2013, Tracing Frictions in The Act of Killing dalam Film Quarterly, Vol. 67, No. 2

Pusat Bahasa Departemen Pendidikan Nasional. 2008. Kamus Besar Bahasa Indonesia. IV. Jakarta: Pusat Bahasa Departmen Pendidikan Nasional.

Scott-Maxwell, Aline. 2020, K-pop flows and Indonesian student pop scenes: situating live Asian pop music in an 'Asian' Australia dalam Media International Australia vol. 175

Sugiharto, I. Bambang. 1996. Postmodernisme: Tantangan Filsafat. Jogjakarta: Kanisius.

Wardhani, Baiq. 2015. “Postmodernisme.” (April). 


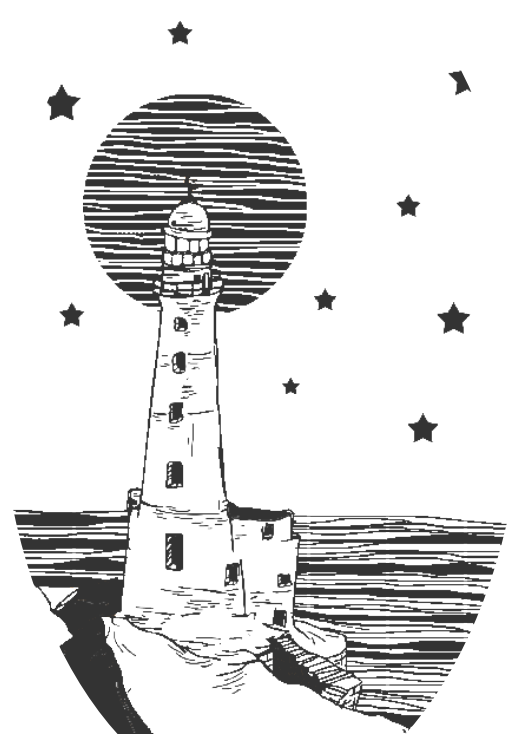




\section{Pedoman Penulisan}

Naskah artikel ditulis dalam bahasa Indonesia atau bahasa Inggris dengan panjang 5000-8000 kata. Lebih dari 8000 kata ditoleransi dengan catatan bahwa kelebihan tersebut sepadan dengan data, informasi, serta analisis dan diskusi yang dikerjakan. Naskah merupakan hasil penelitian maupun refleksi kritis atas sebuah pemikiran, teori, atau metodologi dalam sosiologi atau ilmu sosial secara umum. Penting diingat bahwa naskah yang diajukan tidak tengah dalam proses pengajuan atau dalam proses telaah (review) di jurnal lain. Pengajuan naskah artikel dilakukan melalui menu submission (pengajuan) di website http://journal.unusia.ac.id/index.php/Muqoddima.

Naskah ditulis dengan menggunakan font Book Antiqua pada program Microsoft Word, dengan ekstensi .doc, .docx, atau .rtf. Sistem penulisan secara umum adalah sebagai berikut:

\section{Judul}

Judul merefleksikan isi tulisan, singat, padaat dan diupayakan menarik minat pembaca. Font sebesar 20 poin, dengan huruf kapital di depan setiap kata (Capitalized Each Word) kecuali kata sambung. Panjang judul tidak lebih dari 10 kata. Hindari menggunakan tanda kurung (...) dalam judul.

\section{Nama dan identitas penulis}

Nama lengkap penulis dicantumkan tanpa gelar akademik, disertai keterangan institusi dan alamat email.

\section{Abstrak dan kata kunci}

Abstrak ditulis dalam bahasa Indonesia dan bahasa Inggris dengan panjang antara 150-250 kata. Abstrak seutuhnya ditulis dalam bentuk naratif memuat kajian, tujuan penelitian, metodologi, temuan, dan argumentasi. Kata kunci maksimal terdiri atas 6 (enam) kata/frasa.

\section{Tubuh artikel}

Tubuh artikel ditulis dengan ukuran huruf 11 poin, kecuali untuk sub judul (13 poin) dan catatan kaki (10 poin). Setiap awal paragraf ditulis menjorok ke dalam sepanjang 1 $\mathrm{cm}$. Penggunaan kata-kata asing dituliskan secara miring (italic). Tubuh artikel memuat empat komponen pokok meliputi (1) pendahuluan, (2) metode/cara kerja, (3) analisis dan diskusi, dan (4) kesimpulan.

\section{Catatan kaki}

Catatan kaki dituliskan hanya jika diperlukan, yakni untuk memberikan keterangan tambahan atas suatu hal spesifik yang tidak sinambung secara langsung bila diletakkan sebagai bagian tubuh artikel. Hindari menggunakan catatan kaki jika berkenaan dengan sumber rujukan teoritis atau sumber data primer.

\section{Daftar Pustaka}

Daftar Pustaka ditulis dengan mengikuti standar format ASA (American Sociological Association). Format ASA juga berlaku dalam penulisan kutipan di tubuh artikel, termasuk 
catatan perut dan catatan kaki (note, footnote).

Berikut ini adalah berapa contoh penulisan isi Daftar Pustaka:

Andreassen A., Bard. 2007. "Human Rights and Legal Empowerment of the Poor", Extreme Poverty and Human Rights Expert Seminar, Geneva 23-24 February 2007, Norwegian Centre for Human rights, University of Oslo.

Fatoni, Muhammad Sulton. 2015. Kapital Sosial Pesantren (Studi Tentang Komunitas Pesantren Sidogiri Pasuruan Jawa Timur). Jakarta: Universitas Indonesia.

Geertz, Clifford. 1965. "Religion: Anthropological Study", dalam David L. Sills (ed.) International Encyclopedia of the Social Sciences. London: Collier-Macmillan Publishers.

Jones, Bobby L., Daniel S. Nagin, dan Kathryn Roeder. 2001. “A SAS Procedure Based on Mixture Models for Estimating Developmental Trajectories." Sociological Methods and Research 29 (3):374-93. Diakses pada 26 April 2005 (https://journals.sagepub. com/doi/10.1177/0049124101029003005).

Kukathas, Chandran. 2002. "Multiculturalism as Fairness: Will Kymlicka's Multicultural Citizenship." Journal of Political Philosophy 5(4):406-427. Diakses pada 27 Mei 2019. (https://onlinelibrary.wiley.com/doi/10.1111/1467-9760.00041)

Keterangan lebih rinci terkait ketentuan penulisan dapat diperiksa dalam Template Artikel MJPRS. 


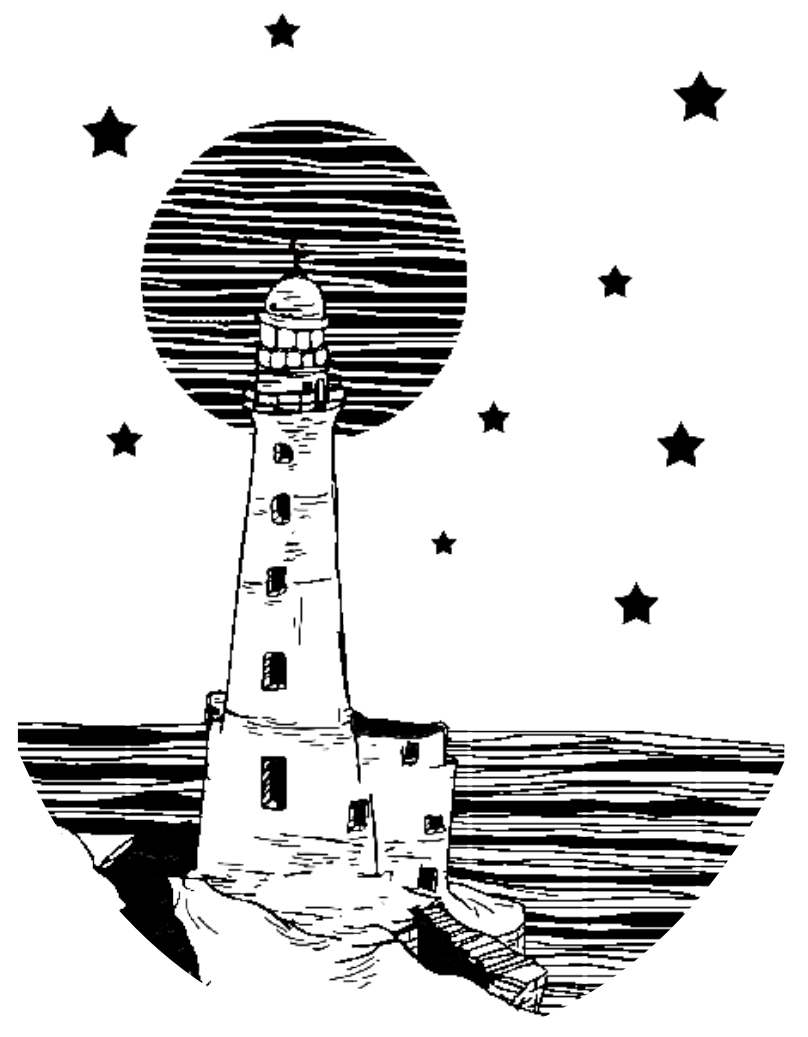



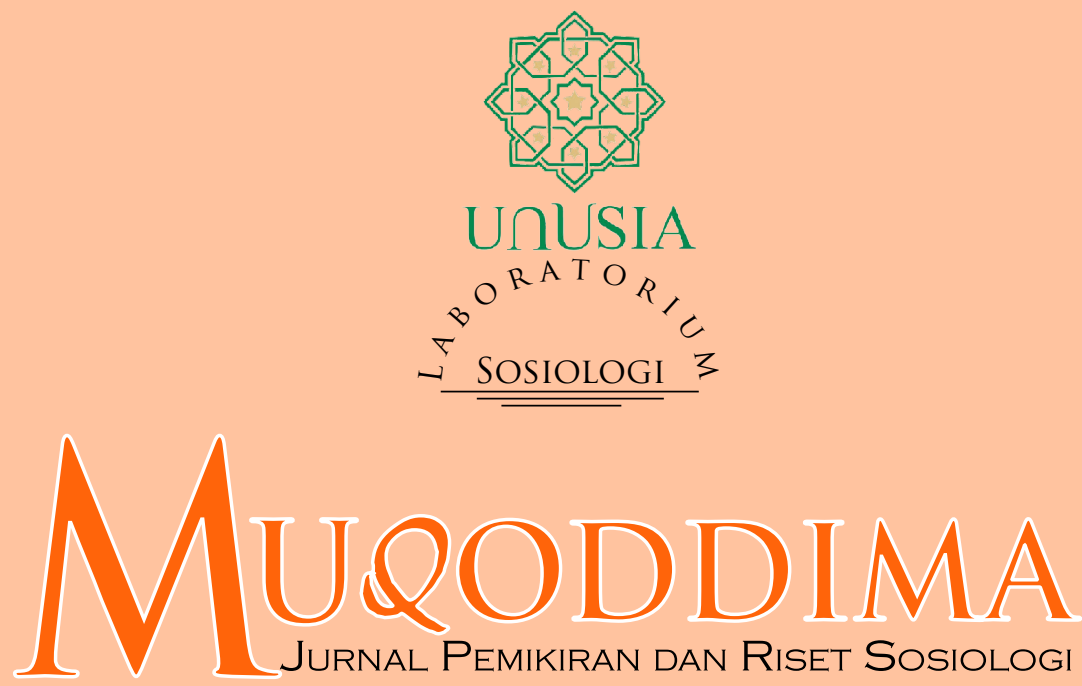